\title{
Inter-community variability in total particle number concentrations in the eastern Los Angeles air basin
}

\author{
N. Hudda, K. Cheung, K. F.Moore, and C. Sioutas \\ University of Southern California, Sonny Astani Department of Civil and Environmental Engineering, $3620 \mathrm{~S}$ Vermont Ave., \\ Los Angeles, CA, 90089, USA
}

Received: 7 April 2010 - Published in Atmos. Chem. Phys. Discuss.: 7 June 2010

Revised: 13 November 2010 - Accepted: 16 November 2010 - Published: 1 December 2010

\begin{abstract}
Ultrafine Particles (UFP) can display sharp gradients in their number concentrations in urban environment due to their transient nature and rapid atmospheric processing. The ability of using air pollution data generated at a central monitoring station to assess exposure relies on our understanding of the spatial variability of a specific pollutant associated with a region. High spatial variation in the concentrations of air pollutants has been reported at scales of $10 \mathrm{~s}$ of $\mathrm{km}$ for areas affected by primary emissions. Spatial variability in particle number concentrations (PNC) and size distributions needs to be investigated, as the representativeness of a monitoring station in a region is premised on the assumption of homogeneity in both of these metrics. This study was conducted at six sites, one in downtown Los Angeles and five located about $40-115 \mathrm{~km}$ downwind in the receptor areas of Los Angeles air basin. PNC and size distribution were measured using Condensation Particle Counters (CPC) and Scanning Mobility Particle Sizer (SMPS). The seasonal and diurnal variations of PNC implied that PNC might vary significantly with meteorological conditions, even though the general patterns at the sites may remain generally similar across the year due to consistency of sources around them. Regionally transported particulate matter (PM) from upwind urban areas of Los Angeles lowered spatial variation by acting as a "homogenizing" factor during favorable meteorological conditions. Spatial variability also increased during hours of the day during which the effects of local sources predominate. The spatial variability associated with PNC (quantified using Coefficients of Divergence, CODs), averaged about 0.3, which was generally lower than that based on specific size ranges. Results showed an inverse relationship of COD with particles size, with fairly uniform values in the particle range
\end{abstract}

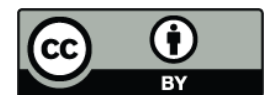

Correspondence to: C. Sioutas (sioutas@usc.edu) which is associated with regional transport. Our results suggest that spatial variability, even in the receptor regions of Los Angeles Basin, should be assessed for both PNC and size distributions, and should be interpreted in context of seasonal and diurnal influences, and suitably factored if values for exposure are ascertained using a central monitoring station.

\section{Introduction}

Numerous recent epidemiological and toxicological studies investigating associations between particulate pollution and health effects have attributed greater risk to ultrafine particles (UFP, diameter less than $\sim 100 \mathrm{~nm}$ ) (Oberdörster et al., 1995; Donaldson et al., 1998; Gong et al., 2007; Xia et al., 2006; Delfino et al., 2005, 2009) compared to particles of greater diameters. In vitro toxicological studies have also shown that ultrafine particles have higher oxidative potential and can penetrate and destroy mitochondria within epithelial cells (Li et al., 2003). Penttinen et al. (2001) found that daily mean number concentration and peak expiratory flow (PEF) are negatively associated and that the effect is most prominent for particles in the ultrafine range. A study by Peters et al. (1997) also found associations between number concentrations of ultrafine PM and lowered PEF among asthmatic adults.

Although current federal standards for particulate matter (PM) are mass-based, there is increasing evidence that a number-based standard might be better suited for UFP concentrations and the associated risks (Englert et al., 2004), since UFP are more numerous and contribute little to PM mass (Hinds, 1999). Current standards are based on $\mathrm{PM}_{2.5}$ and $\mathrm{PM}_{10}$, although poor correlation has been reported between PNC (dominated by UFP) and $\mathrm{PM}_{2.5}$ (dominated by accumulation mode particles) (Sardar et al., 2004). Not only

Published by Copernicus Publications on behalf of the European Geosciences Union. 
is $\mathrm{PM}_{2.5}$ not an adequate surrogate measure, but also such data is often used from central monitoring stations to ascertain exposure values that might lead to exposure misclassification due to spatial variability in UFP concentrations (Delfino et al., 2005). Urban environments are often characterized by a complex set of factors (sources, meteorology, solar radiation, mixing height, and topography amongst others) that can influence not only the particulate matter (especially ultrafine particles) concentration, but also its spatial variability (Costabile et al., 2009). Using a central monitoring station assumes a homogeneous distribution of UFP over large spatial scales, but recent works of Kim et al. (2002), Zhu et al. (2002a, b), Tuch et al. (2006), Puustinen et al. (2007), Krudysz et al. (2009) and Moore et al. (2009) all suggest that UFP vary spatially at local as well as regional scales and use of central monitoring stations can lead to a bias in exposure assessment given the variability (Cyrys et al., 2008; Puustinen et al., 2007; Jerrett et al., 2005; Monn et al., 2001).

In urban areas, a dominant source of UFP is primary emissions from vehicular sources (Shi et al., 2001; Phuleria et al., 2005; Fine et al., 2004b) and as much as $80 \%$ particles can be in the UFP size range (Morawska et al., 1998; Shi et al., 2001; Sioutas et al., 2005). Other combustion sources, such as food cooking and wood burning, can also be sources of ultrafine particles to the atmosphere (Kleeman et al., 1999; Schauer et al., 2001). Shi et al. (2001) have shown that nanoparticles from fresh emissions can be persistent in urban atmospheres, given the multiplicity of sources. Zhu et al. (2002a, b, 2005, 2006) have shown that UFP concentrations can decay exponentially with distance from the freeways. Consequently, given their short lifetimes, the gradient of UFP concentration in atmosphere can be strong (Sioutas et al., 2005).

In addition to primary, or direct, ultrafine particle emissions, photochemical reactions in the atmosphere may also be responsible for the formation of secondary ultrafine particles. Kulmala et al. (2004) reviewed particle formation by secondary processes and showed that such particle formation events are more distinct in summer. Particle formation rates depend strongly on the intensity of solar radiation, but the exact mechanism by which the process occurs is not fully understood (Zhang et al., 2002). Once formed, particles are transformed in the atmosphere, by coagulation and condensation of semivolatile vapors on their surface as they are advected downwind. This long-range transport as well as photochemical particle formation in the atmosphere can lead to increased particle number observations downwind of urban areas (Kim et al., 2002; Fine et al., 2004b; Verma et al., 2009; Ning et al., 2007).

In large urban areas like the Los Angeles air basin (LAB), both primary direct emissions and also transported aged aerosols from locations upwind (some potentially distant) contribute to the observed PM levels. This spatial transport of PM, coupled with local factors like the micrometeorology of a site and its exposure to local sources, can produce distinct diurnal patterns, which vary spatially over scales at which inter-community variability can be assessed. It has been suggested (Turner et al., 2008) that secondary formation during regional transport can be a homogenizing factor on spatial variability. However, in 2002 and 2003, investigators in the USC Children's Health Study (Sardar et al., 2004; Singh et al., 2006) made measurements at several areas in LAB and found that, although some sites may exhibit similar diurnal patterns, PNC may still vary considerably, and have only a modest correlation even among proximate sites. Lianou et al. (2007) found that the spatial variation in PNC might far exceed that in particulate mass concentrations. Fine et al. (2004a, b) have also shown that sites in the receptor areas of LAB can have different particle size distribution patterns as well as different PNC diurnal patterns.

Thus, in order to better quantify the risk that ultrafine PM (UFP) poses to human health, it is necessary to characterize its spatial variability to better assess the potentially different population exposure to UFP, both in terms of particle numbers as well as the size distribution, compared to PM mass.

\section{Experimental methods}

This study is a second phase of an investigation of the intraand inter-community variability of PNC in the greater Los Angeles Area. The earlier phase focused exclusively on the area of the Los Angeles - Long Beach Harbor and has been reported in Moore et al. (2009) and Krudysz et al. (2009).

This study was conducted at five sites in eastern Los Angeles air basin and another site in downtown Los Angeles during November 2008-December 2009. Site Information is provided in Table 1 and the actual locations of these sites are shown in Fig. 1. Highways and major arterials, common sources of ultrafine particles, are identified in Fig. 1. The distances to freeways are also tabulated in Table 1. The sites in the receptor area were within $50 \mathrm{~km}$ of each other in the E-W direction and $20 \mathrm{~km}$ in the N-S direction. Sampling sites were located in areas where there were no known major contributors to UFP, except for local traffic (e.g., residential neighborhoods).

\section{Site descriptions}

Site "USC" is located in downtown Los Angeles and is the Southern California Particle Center Supersite located at the University of Southern California (USC) where extensive air quality measurements have previously been reported (Sardar et al., 2005; Moore et al., 2007). It is an urban background site influenced by traffic from the I-110 freeway located approximately $120 \mathrm{~m}$ to the west. This site was chosen to represent urbanized areas of Los Angeles, which are heavily impacted by traffic. USC site is classified as the "source" or the "urban background" site in this paper as it is representative of the prevailing conditions in western part of Los Angeles 
Table 1a. Site information including the designation code, geographic co-ordinates, site and equipment elevations, sampling period and (CPC) data recovery ${ }^{\mathrm{a}}$.

\begin{tabular}{lllrrrr}
\hline Site ID & Latitude & Longitude & $\begin{array}{r}\text { Site } \\
\text { elevation }(\mathrm{m})\end{array}$ & $\begin{array}{r}\text { Inlet } \\
\text { elevation }(\mathrm{m})\end{array}$ & $\begin{array}{r}\text { Distance from } \\
\text { nearest Freeway (m), } \\
\text { [Average Vehicles/day] }\end{array}$ & $\begin{array}{r}\text { Sampling } \\
\text { period }\end{array}$ \\
\hline USC & $34^{\circ} 1^{\prime} 9^{\prime \prime} \mathrm{N}$ & $118^{\circ} 16^{\prime} 39^{\prime \prime} \mathrm{W}$ & 61 & 4.6 & $120,[112000]$ & $11 / 17 / 2008-12 / 21 / 2009$ \\
recovery $(\%)$
\end{tabular}

a The SMSP were operated at sites USC, UPL and AGO from 5 September 2009-21 December 2009 at greater than $90 \%$ data recovery.

Table 1b. Relevant Information on Potential PM Sources.

\begin{tabular}{ll}
\hline Site ID & Relevant Information on Potential PM Sources \\
\hline USC & Located next to a gasoline dominated freeway in a parking lot, urban background site \\
DIA & Located on a hill in a parking lot, at over $100 \mathrm{~m}$ elevation from the neighboring freeway \\
UPL & Located at the foothills of mountain range, limited local sources, regional site in terms of northern extent of LAB \\
VBR & Located in a residential area, rural regional site \\
RUB & Located behind an office building near a low trafficked street and a freeway \\
AGO & Located in an agricultural research facility near a university, freeways nearby, most inland, regional background site \\
\hline
\end{tabular}

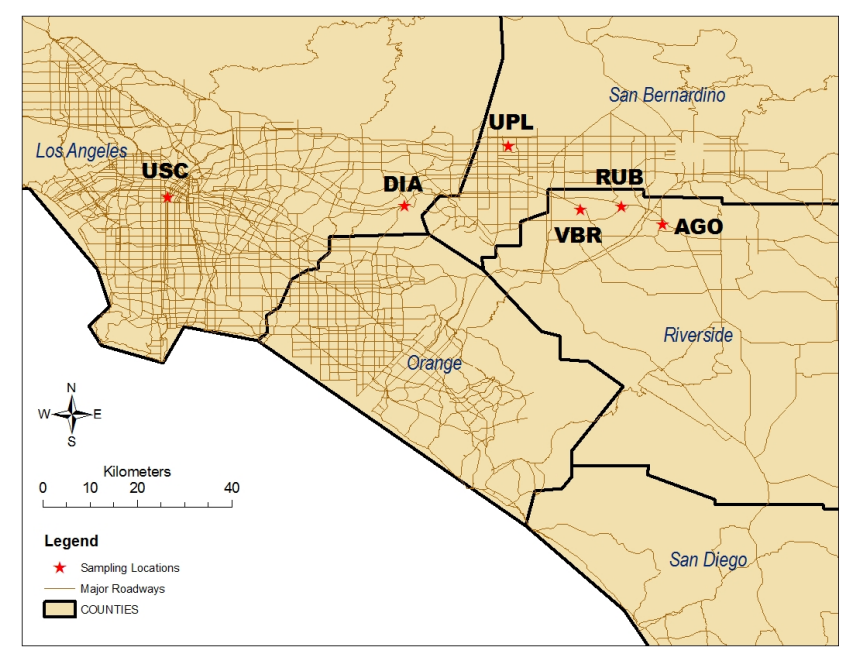

Fig. 1. Location of sampling sites in Los Angeles air basin.

basin where the urban center is located in the basin. It is contrasted against the effect of transport and aging observed at "receptor" or "regional background" sites, which are downwind in the eastern region of the basin towards which the meteorology of the basin transports the pollutants from the source region.

The Diamond Bar site "DIA" is located about $60 \mathrm{~km}$ inland from the Pacific Ocean and $40 \mathrm{~km}$ east of USC site. The site is located $200 \mathrm{~m}$ south of the CA-60 freeway. It is the first site in eastern LAB cluster along a typical trajectory over which primary aerosols emitted in the west and central parts of LA are being transported during atmospheric aging (Pandis et al., 1992). However, it is located on a hill in the prominent upwind direction and is therefore not directly impacted by traffic emissions throughout the day.

The Upland site "UPL" is located in a mobile home park in Upland that is about $80 \mathrm{~km}$ inland from the ocean and about $60 \mathrm{~km}$ east of USC site. It is over $2 \mathrm{~km}$ away from the neighboring freeways and surrounded by low trafficked streets. The site is located close the base of the San Gabriel Mountains, which act as a barrier for further transport of aerosols in northern direction The site is therefore influenced mostly by the aged aerosol advected eastwards from urban Los Angeles (Fine et al., 2004b).

The Van Buren site, "VBR", is located $97 \mathrm{~km}$ inland and $57 \mathrm{~km}$ east of USC at a South Coast Air Quality Monitoring District (AQMD) sampling station in a rural residential neighborhood. It is $3 \mathrm{~km}$ (south) from the nearest freeway and the major roadways next to the site have low traffic load. A substantial component of PM at this site can be attributed to the PM advected from the west to this area after hours of aging. This site has also been discussed in (Pakbin et al., 2010; Moore et al., 2010).

The Rubidoux site, "RUB", is located about $100 \mathrm{~km}$ inland from the ocean and $80 \mathrm{~km}$ east of USC (and $8 \mathrm{~km}$ east of VBR) at an AQMD sampling station. It is in vicinity of 
CA-60, situated about $200 \mathrm{~m}$ to its south. This site is impacted by similar sources as VBR, with the additional influence of the neighboring freeway.

The site "AGO" is located in Riverside within the premises of the Citrus Research Center and the Agricultural Experiment Station of the University of California, Riverside. It is $8 \mathrm{~km}$ further east of RUB, and similarly influenced in terms of PM sources. It is about $750 \mathrm{~m}$ southwest of CA-60/I-215. This was the furthermost inland site, located at the periphery of what can be termed as the populous region of the LAB, and represents a regional background in terms of the eastern extent of LAB. Except for the neighboring freeway, it has no other primary emission sources nearby.

Particle number size distributions (PNSD) were measured at USC, the urban background site located in the source region of the LAB as well as at UPL and AGO, both in the receptor region of the basin, with UPL being at its northern edge and AGO at its eastern.

\subsection{Instrumentation}

Total particle number concentrations were measured at all sites using Condensation Particle Counters (CPC, Model 3022A, TSI, Inc., Shoreview, MN). A Scanning Mobility Particle Sizer (SMPS, Model 3936, TSI, Inc., Shoreview, $\mathrm{MN}$ ) was used at select sites to measure the particle size distributions. The CPC used can measure with about $100 \%$ efficiency particles above $20 \mathrm{~nm}$ and has $50 \%$ detection efficiency for a diameter of $7 \mathrm{~nm}$. The upper size range for detection is $3 \mu \mathrm{m}$. The CPC recorded data at one-minute interval. The sampling rate was maintained at $1.5 \pm 0.2$ liters per minute and the air stream was not conditioned prior to sampling. The SMPS system consists of a long Differential Mobility Analyzer (DMA Model 3081, TSI, Inc., Shoreview, MN) and CPC 3022A (operating at $0.3 \pm 0.03$ liters per minute, sheath air was not pre-conditioned), set to $5 \mathrm{~min}$ scans covering the size range $14-736 \mathrm{~nm}$. TSI software Aerosol Instrumentation Manager was used to collect data from both the CPC and the SMPS. Weekly site visits were made to ensure proper equipment operation and perform maintenance. Flow rates were checked weekly and maintained within the range indicated in this section. All inlets used to sample ambient aerosols were copper tubes of $1 \mathrm{~cm}$ diameter.

Meteorological data, i.e., temperature, relative humidity, wind speed and direction amongst other parameters were collected using Vantage Pro 2 Weather Stations (Davis Instruments, Hayward, CA). The meteorological station was placed above the enclosure and the wind vane sampled at a height of $5 \mathrm{~m}$ from the ground surface. The meteorological data were compared with neighboring AQMD stations with more standardized meteorological equipments, and only for wind speed and direction slight differences were observed. This was because of lower height of our equipment. Even then, the diurnal patterns of these parameters were consistent with those reported by AQMD.

All particle equipment was placed in an air-conditioned enclosure, but there were instances in summer when temperatures exceeded the optimum operation temperature for the equipment $\left(\sim 35^{\circ} \mathrm{C}\right)$ and the data were screened out for such instances. At times during summer, water condensation was observed in the CPC. The CPC reservoirs were drained and the data for such events has been excluded from analysis.

\subsection{Data processing and validation}

Given the high temporal resolution of the data (i.e., 1-min particle number concentration, 5-min size distribution scans, wind speed, wind direction, temperature, relative humidity, and other parameters collected up to a year at 6 sites) it was not practical to provide detailed description and interpretation of all data. Therefore, in this paper we present data as hourly averages and for consistency, the hourly averages are reported in local time for the entire year. All collected data were thoroughly reviewed for irregularities, similar to the work of Puustinen et al. (2007). Data were not included in averages if the counts reported were below 1000 particles $/ \mathrm{cm}^{3}$ or exceeded $10^{6}$ particles $/ \mathrm{cm}^{3}$, which were associated with electronic errors in CPC. The data recovery rates are reported in the Table 1 . The lowest data recovery was reported for June 2009, when we experienced excessive water condensation inside the CPC butanol reservoirs. Data from site VBR are not reported after April 2009, as the measured concentrations were unreliable due to CPC malfunction. CPCs were operated side-by-side at USC for a 24-h period before the commencement of the sampling campaign to ascertain consistency. Data analysis indicated that the average slope of a CPC against the "mean" CPC was $0.98 \pm 0.16$ and the range was $0.72-1.26$. At the end of the study, the CPCs were set up to run side-by-side for over $48 \mathrm{~h}$ and each CPC concentration was compared to the concentrations measured by a factory-calibrated CPC. The correlation coefficient between all the CPCs was in the range 0.86-0.99, even though two CPC reported an average slope less than 0.7 against a factory-calibrated CPC. We elected to compare CPCs with a unit calibrated by the factory instead of the mean of the CPC values because the CPCs had been operating in field continuously for over two years, and several units used in earlier studies by our group had shown performance deterioration with prolonged field use. The data were corrected (assuming a linear deterioration in performance over the span of operating period) to compensate for the inconsistency between the CPCs. No corrections were made for diffusion losses, due to different inlet lengths, because our earlier characterization showed that they are insignificant (Moore et al., 2009).

Statistical methods used for analysis in the present study are discussed in our earlier work (Moore et al., 2009; Krudysz et al., 2009). The paper reports coefficients of 
divergence (COD) to analyze the relationship between sites. While parameters such as the correlation coefficient are often used to quantify a linear relationship between data sets, and in this context would quantify a fraction of observations at a particular site that can be explained in terms of simultaneous observations made at another sites, a high correlation between paired sites would only imply uniform temporal variation (Lianou et al., 2007), but not the variability in itself amongst sites. The COD is in this context more suitable to characterize this spatial variability (Wilson et al., 2005; Krudysz et al., 2009; Moore et al., 2009). It is defined as:

$\mathrm{COD}_{j k}=\sqrt{\left(\frac{1}{n} \sum_{i-1}^{n}\left(\frac{x_{i j}-x_{i k}}{x_{i j}+x_{i k}}\right)^{2}\right)}$

where $j, k$ are two sites, $n$ is the number of simultaneous observations. The value of COD varies from 0 (the concentration being identical at the two sites) to 1 (the concentration being different). A low value of COD represents a high level of homogeneity between sites and a value of COD above roughly 0.2 is considered to be generally heterogeneous (Wilson et al., 2005).

\section{Results and discussion}

\subsection{Meteorology}

Meteorological conditions can influence ultrafine particle concentrations significantly, but the Los Angeles area exhibits relatively limited diurnal and seasonal variation, as was the case during the study period. The mesoscale meteorology of the area that is most relevant in context of this study is the interaction of coastal winds with the San Gabriel Mountains. The pollution generated in west LA during the morning is transported over the course of several hours of aging toward the eastern portion of the Los Angeles Basin and up the southern flanks of the San Gabriel Mountains. The strong subsidence inversion layer, frequently present over the area in the winter and almost always in the summer, limits the vertical dispersion and westerly sea breeze, which sets in during the afternoons, transports this pollution further inland. This is also evident from inset plots in Figs. 2a, 3a, 4a showing vector average wind direction during three months (January, May and September) of 2009. Across the sites, winds were observed from the west during afternoons, at relatively higher speeds than most hours of the day. As the mixing layer stabilizes during evenings, the trapped pollutants can linger overnight and then be re-entrained to the surface during early morning hours in east LA ( $\mathrm{Lu}$ et al., 1994, 1995). The particle number concentrations and the size distributions will be discussed in this context.

Meteorology of the Los Angeles Basin and its effects on air pollutant's movements has been discussed in greater detail by Blumenthal et al. (1978), Lu et al. (1994, 1995),
McElroy et al. (1986, 1983), Shultz et al. (1982), Ulrickson et al. (1990) and Wakimoto et al. (1986). Tables 2 and 3 present an overview of select data for the stable meteorological conditions at sampling sites. Air temperatures do not vary much across sites and the seasonal trend across sites is quite similar, with slightly lower temperatures observed at sites further inland during winter. January was warmer than February, and September across sites was at least as warm as or warmer than August, which is quite typical of the area. The relative humidity at all sites was consistent during sampling period, except during Santa Ana winds that brought in dry winds from the desert, due to a synoptic high-pressure system, also typical of this time of the year in southwest Unites States. The predominant wind direction at the sites, except for winter months (December-February), was from the west, with stronger winds from the west recorded during afternoons and nighttime stagnation being the most dominant winds speed characteristics in the basin.

\subsection{Diurnal and seasonal variations}

In this section, particle number concentrations (PNC) for different sites are discussed as diurnal, hourly averaged, data for selected months. Alternate months of the year were chosen (unless another particular month was more relevant) to maintain clarity in graphs and to illustrate the similarities/differences across the diurnal, seasonal and spatial trends observed at these sites. The relative standard error was less than 5\%. The hourly average data presented is an arithmetic mean. Further, the CODs are discussed in context of the spatial variability.

Figure 2a shows the PNC hourly averages across the odd months of the year at USC. This site is regarded as a typical urban background site in Los Angeles. In the cooler months of late spring and late fall, a characteristic early morning peak, associated with mostly light-duty gasoline vehicle morning commute, is observed from 05:00-10:00 h. Advancing into summer months, this peak is not as robust and eventually flattens, as higher temperatures during the early mornings increase mixing heights, thus enhancing dispersion, and also lead to possible volatilization of semivolatile organics bound to PM from traffic emissions (Biswas et al., 2007; Ning et al., 2007). However, another peak emerges, which has its crest in early afternoon, and in summer months is associated with the highest diurnal values for PNC. This peak has been identified with the secondary particle formation, and is consistent with the work of Moore et al. (2009, 2007), Ning et al. (2007) and Verma et al. (2009). The presence of this peak implies that secondary photochemical formation can contribute to PNC in some months as significantly as primary emissions from local sources. Similar results have been reported by Costabile et al. (2009) and Wehner et al. (2007). During the cooler months of the year, another peak is observed in the evenings and early night, which is weaker during summers, possibly related to particle 


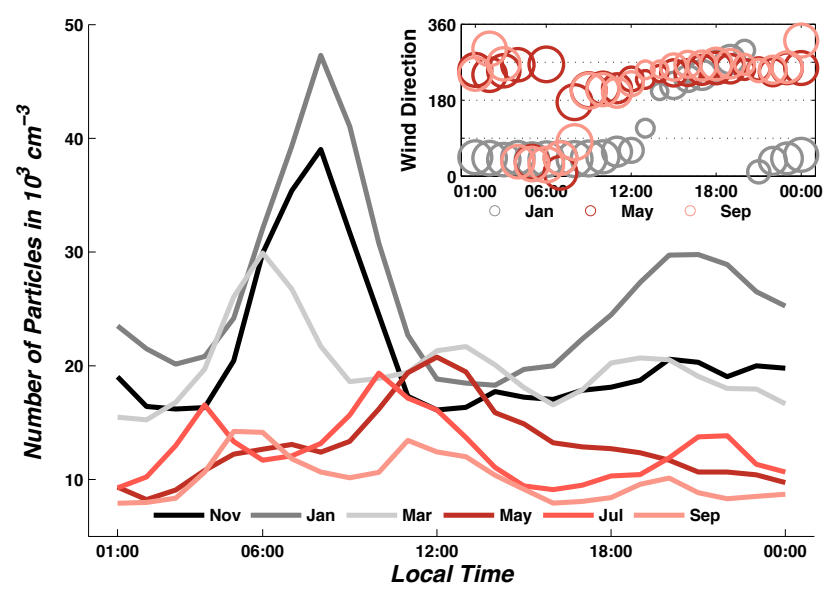

Fig. 2a. Hourly average particle number concentration at USC plotted for hours of the day in local time. The relative standard error for the hourly averages reported above was less than $2 \%$. The inset is a plot of vector averaged wind direction (WD) with the bubble area weighed to wind speed plotted for hours of the day in local time.

formation by condensation of semivolatile vapors emitted by traffic during preceding hours. The depression of the atmospheric mixing layer during later hours of the day in cooler months can further enhance the production of these elevated particle concentrations, and its effect is most pronounced in peak winter months (December-February), when night time concentrations can reach ca. $30000 \mathrm{~cm}^{3}$. Biswas et al. (2007) have previously reported a similar data pattern. The observations at USC suggest that PNC can vary significantly at a site across seasons (morning commute peak in winters $\sim 40000 \mathrm{~cm}^{3}$ and in summers $\sim 15000 \mathrm{~cm}^{3}$ ), even though they may be associated with consistent local emission sources, all due to different meteorological conditions. Thus, when considering exposure to UFP, especially using a number-based metric, meteorological conditions and secondary sources can be of as much consequence as direct emissions from local sources.

Figure $2 b$ and c compare the average particle size distribution of during different time periods of the day at USC during September and December of 2009. As discussed above, the photochemical activity-related peak (observed during the afternoon period 12:00-14:00 h, by when previously formed particles grow to a size range that is measurable by SMPS) is very robust in September and weakens progressively through the fall and into December. Insets in Fig. $2 b$ and $c$ further elucidates this point by comparing the particle size distribution during 10:00-14:00 h between September and December, i.e., the warmer and cooler months of our sampling campaign. In September, a simultaneous rise in total particle numbers and the sub- $25 \mathrm{~nm}$ particles can be seen and is attributed to photochemical formation. The possibility of these particles being associated with fresh (traffic) emissions is unlikely because analysis of traffic trends of the neighbor-

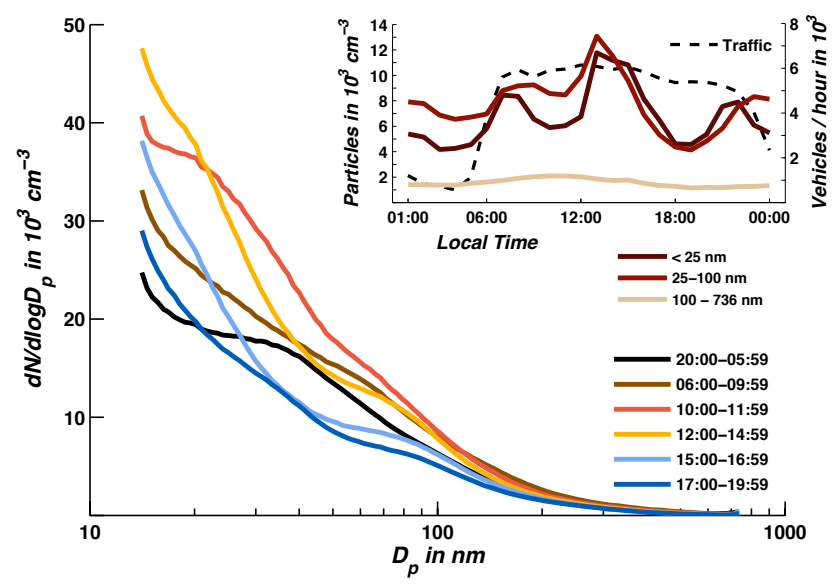

Fig. 2b. Average Size Distribution of Particles during six time periods (local time) of the day at USC during September 2009.

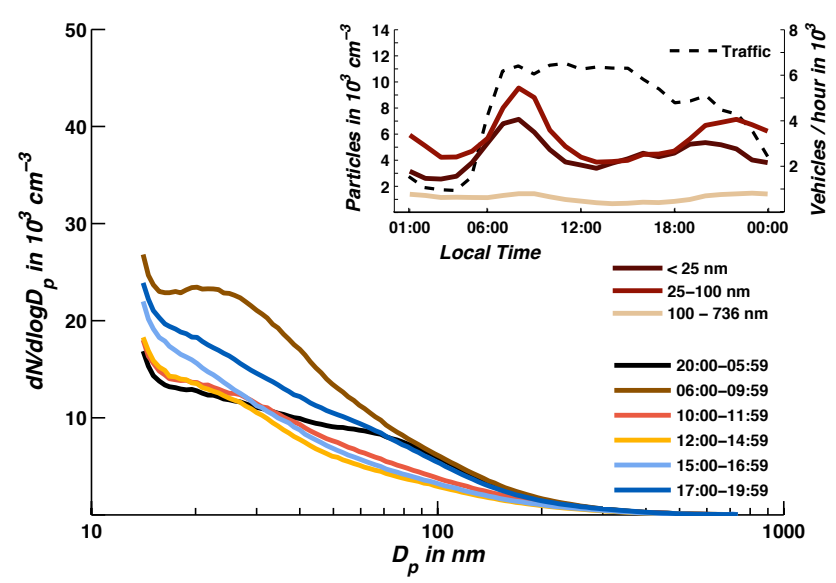

Fig. 2c. Average Size Distribution of Particles during six time periods (local time) of the day at USC during December 2009.

ing freeway, (the major source of fresh emissions at USC), confirms no significant changes either during the hours associated with photochemical activity, or across seasons. Further, the increase in atmospheric mixing height during this time of day would decrease the concentrations of PM of primary origin. Traffic profiles (vehicle count/h for the month of September and December) are also shown in the inset figures. The tri-modal diurnal profile observed at USC during warmer months in Fig. 2a is limited to sub-50 nm particles, while the seasonal variation of the diurnal patterns for particles $>100 \mathrm{~nm}$ is not clearly evident. This is a distinctly different pattern than that observed at the inland sites, and illustrates a size distribution that is characteristically associated with urban sites in proximity to primary emissions from vehicles (Morawska et al., 2007; Ronkko et al., 2006, 2007).

Figure 3a shows monthly-averaged diurnal particle number concentrations across six months of the year at UPL, the northern receptor site (i.e. November, January, Februar, 
Table 2. Prevailing Wind Direction and Speed at sampling sites.

\begin{tabular}{|c|c|c|c|c|c|c|c|c|c|c|c|c|c|}
\hline \multicolumn{14}{|c|}{ Dominant Wind Direction and Wind Speed } \\
\hline Month & Nov & Dec & Jan & Feb & Mar & Apr & May & Jun & Jul & Aug & Sep & Oct & Nov \\
\hline $\mathrm{AGO}$ & \multicolumn{2}{|c|}{2008} & & \multicolumn{10}{|c|}{2009} \\
\hline WD (deg) & SW & $\mathrm{E}$ & $\mathrm{E}$ & $\mathrm{E}$ & W & $\mathrm{W}$ & $\mathrm{W}$ & W & W & W & W & W & $\mathrm{E}$ \\
\hline $\mathrm{WS}(\mathrm{m} / \mathrm{s})$ & 0.70 & 0.89 & 1.21 & 0.93 & 1.21 & 1.31 & 1.17 & 1.23 & 1.13 & 1.04 & 0.96 & 1.37 & 0.93 \\
\hline $\mathrm{SD}(\mathrm{m} / \mathrm{s})$ & 0.70 & 0.81 & 1.35 & 0.82 & 1.22 & 1.21 & 1.10 & 1.16 & 1.21 & 1.13 & 1.23 & 1.55 & 1.04 \\
\hline DIA & & & & \multicolumn{10}{|c|}{2009} \\
\hline Month & & & & Feb & Mar & Apr & May & Jun & Jul & Aug & Sep & Oct & Nov \\
\hline WD (deg) & & & & $\mathrm{S}$ & $\mathrm{S}$ & SW & $\mathrm{S}$ & W & W & W & $\mathrm{S}$ & W & $\mathrm{S}$ \\
\hline $\mathrm{WS}(\mathrm{m} / \mathrm{s})$ & & & & 0.62 & 0.47 & 0.53 & 0.50 & 0.41 & 0.40 & 0.38 & 0.31 & 0.39 & 0.35 \\
\hline $\mathrm{SD}(\mathrm{m} / \mathrm{s})$ & & & & 0.81 & 0.48 & 0.48 & 0.40 & 0.30 & 0.33 & 0.36 & 0.32 & 0.56 & 0.55 \\
\hline RUB & \multicolumn{2}{|c|}{2008} & & \multicolumn{10}{|c|}{2009} \\
\hline Month & Nov & Dec & Jan & Feb & Mar & Apr & May & Jun & Jul & Aug & Sep & Oct & Nov \\
\hline WD (deg) & NW & $\mathrm{N}$ & $\mathrm{N}$ & $\mathrm{N}$ & W & W & W & W & W & W & W & W & NW \\
\hline $\mathrm{WS}(\mathrm{m} / \mathrm{s})$ & 0.53 & 0.96 & 2.38 & 0.78 & 0.97 & 0.84 & 0.84 & 0.71 & 0.70 & 0.62 & 0.62 & 1.00 & 1.28 \\
\hline $\mathrm{SD}(\mathrm{m} / \mathrm{s})$ & 0.75 & 1.49 & 2.66 & 0.98 & 1.20 & 0.63 & 0.56 & 0.57 & 0.60 & 0.54 & 0.67 & 1.48 & 0.37 \\
\hline UPL & \multicolumn{2}{|c|}{2008} & & \multicolumn{10}{|c|}{2009} \\
\hline Month & Nov & Dec & Jan & Feb & Mar & Apr & May & Jun & Jul & Aug & Sep & Oct & Nov \\
\hline WD (deg) & W & $\mathrm{N}$ & $\mathrm{N}$ & W & SW & SW & W & W & $\mathrm{W}$ & W & W & W & W \\
\hline $\mathrm{WS}(\mathrm{m} / \mathrm{s})$ & 0.39 & 0.48 & 0.52 & 0.56 & 0.86 & 1.14 & 1.15 & 1.19 & 1.11 & 1.01 & 0.90 & 0.80 & 0.65 \\
\hline $\mathrm{SD}(\mathrm{m} / \mathrm{s})$ & 0.37 & 0.46 & 0.47 & 0.53 & 0.69 & 0.94 & 0.92 & 0.89 & 1.05 & 0.93 & 0.87 & 0.70 & 0.51 \\
\hline VBR & \multicolumn{2}{|c|}{2008} & & \multicolumn{10}{|c|}{2009} \\
\hline Month & Nov & Dec & Jan & Feb & Mar & Apr & May & Jun & Jul & Aug & Sep & Oct & Nov \\
\hline WD (deg) & W & W & $\mathrm{N}$ & $\mathrm{W}$ & SW & W & SW & W & W & SW & W & W & W \\
\hline $\mathrm{WS}(\mathrm{m} / \mathrm{s})$ & 0.45 & 0.64 & 2.04 & 0.67 & 0.92 & 1.01 & 1.03 & 1.09 & 1.01 & 0.92 & 0.88 & 1.02 & 0.43 \\
\hline $\mathrm{SD}(\mathrm{m} / \mathrm{s})$ & 0.81 & 1.18 & 2.27 & 0.92 & 1.08 & 1.03 & 0.89 & 0.92 & 1.00 & 0.90 & 1.02 & 1.19 & 0.56 \\
\hline USC & & & & \multicolumn{10}{|c|}{2009} \\
\hline Month & & & Jan & Feb & Mar & Apr & May & Jun & Jul & Aug & Sep & Oct & Nov \\
\hline WD (deg) & & & $\mathrm{NE}$ & $\mathrm{NE}$ & W & $\mathrm{W}$ & W & W & W & W & W & $\mathrm{NE}$ & $\mathrm{NE}$ \\
\hline $\mathrm{WS}(\mathrm{m} / \mathrm{s})$ & & & 2.23 & 2.41 & 2.44 & 2.71 & 2.50 & 2.53 & 2.66 & 2.74 & 2.45 & 2.58 & 2.34 \\
\hline $\mathrm{SD}(\mathrm{m} / \mathrm{s})$ & & & 0.86 & 0.97 & 1.04 & 1.16 & 0.96 & 1.04 & 1.05 & 1.12 & 1.02 & 1.05 & 0.77 \\
\hline
\end{tabular}

May, August and September). A bi-modal diurnal distribution is observed at this site, with a morning time peak, similar to USC, corresponding to morning commute during 06:00-10:00 $\mathrm{h}$ in winter months that is not as robust during summer. This winter peak is a compounded effect of vehicular emissions and lower mixing height in winter mornings. (This is clearly evident in the inset in Fig. 3c. A gradual increase in concentration is observed as the winter progresses. The formation of strong surface-based temperature inversions that can lead to almost no vertical mixing (during winters) of the transported PM load, coupled with condensational growth of particles, is responsible for the extended late evening and early night peaks observed at UPL, when PNC plateau overnight. Concentrations as high at $15000 \mathrm{~cm}^{3}$ can be observed during winter nights compared to only ca. $10000 \mathrm{~cm}^{3}$ during summer. The nighttime peak is flatter, broader, and persists longer than the morning traffic peak, and has concentrations that are comparable if not higher than the morning peak, thus producing maximum diurnal concentrations during the night, when local emissions are at their lowest. In comparison, the maximum concentration at USC in the evenings is about half of the morning 
Table 3. Temperature $\left({ }^{\circ} \mathrm{C}\right)$ and Relative Humidity $(\%)$ at sites during sampling period.

\begin{tabular}{|c|c|c|c|c|c|c|}
\hline \multirow{2}{*}{$\begin{array}{l}\text { Sites } \\
\text { Months }\end{array}$} & \multicolumn{2}{|c|}{ USC } & \multicolumn{2}{|c|}{ UPL } & \multicolumn{2}{|c|}{ AGO } \\
\hline & $\mathrm{RH}$ & Temp & $\mathrm{RH}$ & Temp & RH & Temp \\
\hline Dec '08 & & & $67 \pm 21$ & $10.7 \pm 5.4$ & $64 \pm 22$ & $11.3 \pm 5.0$ \\
\hline Jan ’09 & $73 \pm 16$ & $14.0 \pm 3.4$ & $52 \pm 25$ & $14.2 \pm 5.9$ & $44 \pm 23$ & $15.4 \pm 5.0$ \\
\hline Feb '09 & $83 \pm 08$ & $12.2 \pm 1.8$ & $64 \pm 24$ & $11.9 \pm 5.6$ & $63 \pm 23$ & $12.1 \pm 5.3$ \\
\hline Mar'09 & $72 \pm 19$ & $13.6 \pm 3.1$ & $67 \pm 18$ & $13.3 \pm 5.3$ & $58 \pm 21$ & $14.0 \pm 5.2$ \\
\hline Apr '09 & $68 \pm 14$ & $14.6 \pm 4.0$ & $59 \pm 22$ & $16.0 \pm 6.6$ & $55 \pm 21$ & $16.0 \pm 6.3$ \\
\hline May '09 & $78 \pm 08$ & $17.5 \pm 1.7$ & $66 \pm 17$ & $19.4 \pm 5.4$ & $65 \pm 17$ & $19.9 \pm 5.3$ \\
\hline Jun ’09 & $76 \pm 07$ & $17.7 \pm 1.1$ & $67 \pm 16$ & $20.2 \pm 4.8$ & $66 \pm 16$ & $19.7 \pm 5.1$ \\
\hline Jul ’09 & $69 \pm 11$ & $22.7 \pm 3.4$ & $60 \pm 19$ & $24.2 \pm 5.5$ & $52 \pm 18$ & $25.9 \pm 6.0$ \\
\hline Aug '09 & $64 \pm 18$ & $22.4 \pm 4.4$ & $61 \pm 20$ & $23.4 \pm 5.7$ & $53 \pm 22$ & $24.9 \pm 6.4$ \\
\hline Sep '09 & $66 \pm 17$ & $23.1 \pm 4.2$ & $56 \pm 22$ & $24.3 \pm 6.4$ & $47 \pm 22$ & $26.0 \pm 6.6$ \\
\hline Oct '09 & $60 \pm 21$ & $19.1 \pm 3.9$ & $57 \pm 23$ & $18.2 \pm 5.9$ & $52 \pm 23$ & $18.8 \pm 5.8$ \\
\hline Nov'09 & $52 \pm 22$ & $16.7 \pm 4.3$ & $54 \pm 23$ & $15.7 \pm 5.9$ & $47 \pm 24$ & $16.6 \pm 5.5$ \\
\hline Dec '09 & $58 \pm 20$ & $13.8 \pm 3.8$ & $72 \pm 19$ & $12.0 \pm 3.6$ & $67 \pm 18$ & $12.6 \pm 2.9$ \\
\hline Sites & \multicolumn{2}{|c|}{ DIA } & \multicolumn{2}{|c|}{ VBR } & \multicolumn{2}{|c|}{ RUB } \\
\hline Months & RH & Temp & RH & Temp & RH & Temp \\
\hline Dec '08 & & & $62 \pm 26$ & $12.7 \pm 5.8$ & $62 \pm 23$ & $12.1 \pm 5.6$ \\
\hline Jan ’09 & & & $44 \pm 29$ & $16.3 \pm 6.7$ & $42 \pm 26$ & $16.2 \pm 6.1$ \\
\hline Feb '09 & $67 \pm 22$ & $67.3 \pm 21.7$ & $68 \pm 25$ & $12.1 \pm 5.7$ & $64 \pm 24$ & $12.8 \pm 5.7$ \\
\hline Mar ’09 & $64 \pm 19$ & $63.5 \pm 19.4$ & $64 \pm 22$ & $14.0 \pm 5.4$ & $58 \pm 21$ & $15.1 \pm 5.7$ \\
\hline Apr '09 & $58 \pm 21$ & $58.2 \pm 21.0$ & $59 \pm 21$ & $16.0 \pm 6.3$ & $54 \pm 21$ & $17.2 \pm 6.6$ \\
\hline May ’09 & $69 \pm 15$ & $68.7 \pm 14.8$ & $68 \pm 17$ & $19.9 \pm 5.1$ & $62 \pm 18$ & $21.4 \pm 5.8$ \\
\hline Jun ’09 & $69 \pm 14$ & $69.0 \pm 13.8$ & $66 \pm 17$ & $21.0 \pm 5.1$ & $65 \pm 16$ & $20.8 \pm 5.2$ \\
\hline Jul' 09 & $58 \pm 18$ & $58.4 \pm 18.4$ & $62 \pm 19$ & $24.7 \pm 6.1$ & $52 \pm 19$ & $28.0 \pm 6.4$ \\
\hline Aug '09 & $55 \pm 22$ & $55.2 \pm 21.7$ & $59 \pm 22$ & $24.2 \pm 6.4$ & $52 \pm 21$ & $26.2 \pm 6.9$ \\
\hline Sep'09 & $53 \pm 22$ & $52.8 \pm 21.7$ & $57 \pm 23$ & $24.8 \pm 6.8$ & $52 \pm 21$ & $26.2 \pm 7.0$ \\
\hline Oct '09 & $56 \pm 24$ & $55.8 \pm 23.9$ & $57 \pm 25$ & $18.5 \pm 6.0$ & $52 \pm 24$ & $19.7 \pm 6.4$ \\
\hline Nov'09 & $51 \pm 25$ & $51.3 \pm 24.8$ & $55 \pm 27$ & $16.2 \pm 6.4$ & $49 \pm 25$ & $17.1 \pm 6.3$ \\
\hline Dec '09 & $68 \pm 16$ & $68.4 \pm 16.4$ & & & $67 \pm 18$ & $13.6 \pm 3.8$ \\
\hline
\end{tabular}

maximum. Other inland sites exhibit a similar pattern, with nighttime maxima being comparable to morning maxima and the highest PNC being observed during winter months. This concentration pattern may lead to a longer period of exposure to higher PNC in inland areas than in areas with greater local emissions nearer the coast.

Figure $3 \mathrm{~b}$ and $\mathrm{c}$ compare the $\mathrm{PNC}$ in various size ranges at UPL. Between the warm September and cool December months there is a marked change in the diurnal pattern for different size ranges. The afternoon peak in concentrations associated with photochemical activity, as observed at USC and later at AGO, is not as prominent at UPL. Even though the PNSD during 10:00-14:00 $\mathrm{h}$ indicates the presence of particles of sizes that could be attributed to photochemical activity, it is not accompanied by a rise in total PNC, as is observed at USC and AGO. A possible explanation is that the contribution of photochemical activity to the total PNC is obscured (and thus not as distinguishable) by the contribution of the advected aerosols from the upwind urban ar- eas of LAB to the overall PNC. Further, since UPL is distant from major freeways, the concentrations of gaseous and semi-volatile organic vapor precursors that participate in secondary particle formation are lower compared to those at USC (or in general in central LAB), which may decrease the degree of PM formation through this pathway. Analysis of particle concentrations less than $25 \mathrm{~nm}$ and total particle concentrations, as reported by the SMPS, during September further corroborate this hypothesis (shown as an inset in Fig. 3b. No significant differences are observed in $\mathrm{PNC}<25 \mathrm{~nm}$ during 10:00-16:00. The results plotted in Fig. 3a show that during 15:00-17:00 $\mathrm{h}$, when the highest wind speeds of the day are observed, the particle concentrations in the range of 25-100 nm increase (while the $14-25 \mathrm{~nm}$ range remains stable). This particle range is typically associated with coagulation and-or growth of preexisting particles via condensation of semi-volatile organics on pre-existing PM (Rodriguez et al., 2007). The increase in that size range later in the afternoon (during other hours of summer days, the concentrations 


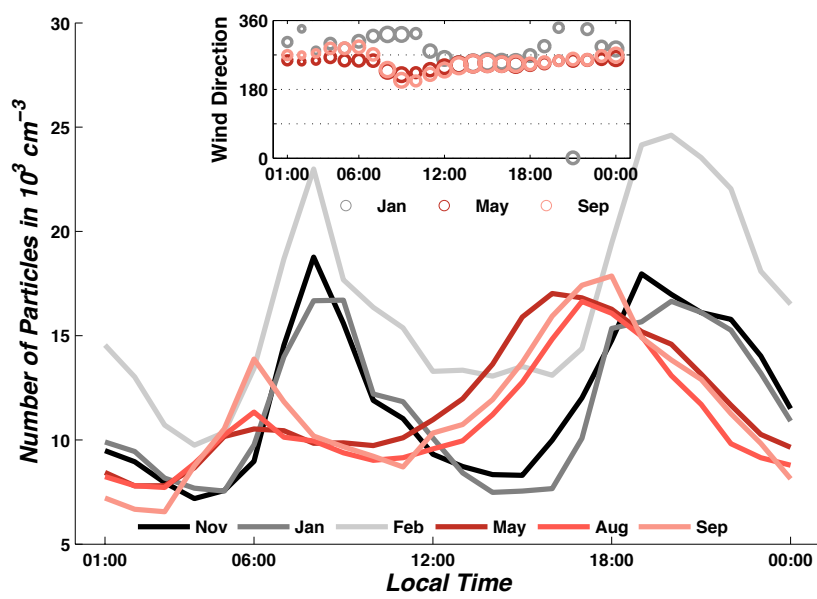

Fig. 3a. Hourly average particle number concentration at UPL for hours of the day in local time. The relative standard error for the hourly averages reported above was less than $2 \%$. The inset is a plot of vector averaged wind direction (WD) with the bubble area weighed to wind speed plotted for hours of the day in local time.

within this size range remain stable) could be due to the arrival of the polluted air mass from Los Angeles. Similar observations have been made by Kim et al. (2002) and Fine et al. (2004b). However, during winters (Fig. 3c) the distribution is uni-modal and the bi-modal distribution is only observed during evening/night with distinctly higher mode diameter during winter. The size range of 14-25 nm, associated with fresh emissions, shows a sharp increase during morning as well as in evening, as evident in the inset (total PNC increases and the mode particle diameter decreases, shifting the distribution towards freshly emitted PM). This is due to the combined effects of local traffic, coupled with the decreasing temperature (increasing the partitioning of semivolatile organic emissions towards the particulate phase) and mixing height (which reduces dispersion), all of which lead to a more pronounced effect of local emissions than that observed during summers. These comparisons suggest that there could be significant distinction in the size distribution profiles observed at sites due to seasonal variation.

Figure 4a shows data for AGO, one of the eastern most regional receptor sites of the study. Diurnal averages are shown for late fall (November), winter (January), spring (March) and summer (May, July and September). The morning peak in the plot can be explained by the morning commute (as this site is near a freeway). However, this morning peak subsides as the year progresses into warmer months when there is greater dispersion of fresh traffic emissions. Similar to UPL, during colder months, there is an evening and early nighttime rise in concentrations, leading to PNCs comparable to that in mornings. This peak diminishes in the summer and returns in September. Figure $4 \mathrm{~b}$ and c contrasts particle size distributions during different time periods of the day. During September it was observed that concentrations

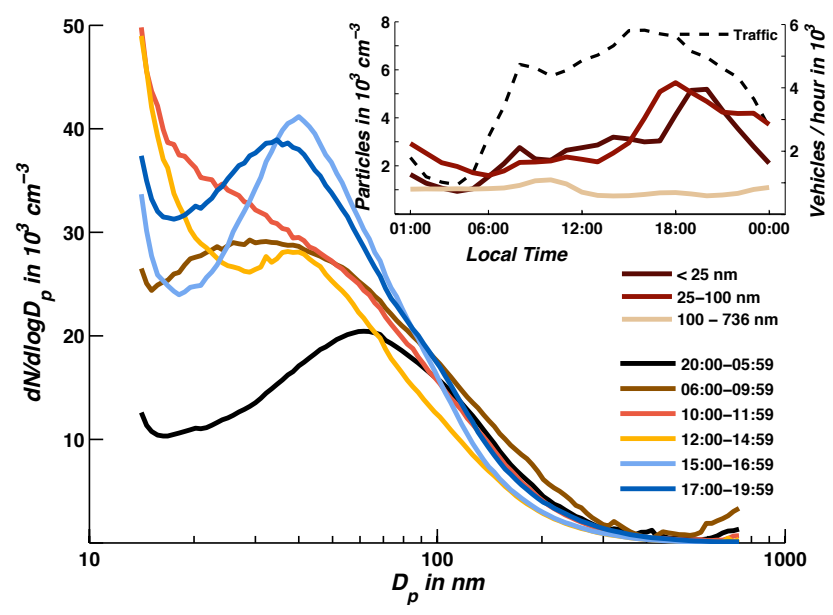

Fig. 3b. Average Size Distribution of Particles during six time periods (local time) of the day at UPL during September 2009.

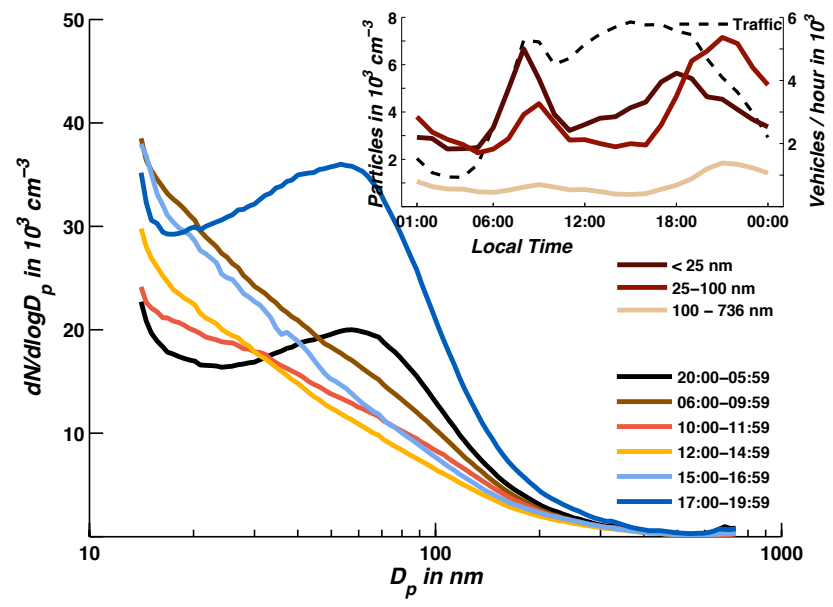

Fig. 3c. Average Size Distribution of Particles during six time periods (local time) of the day at UPL during December 2009.

of smaller particles $(<25 \mathrm{~nm})$ increase during the hours coincident with strong solar irradiance and the mode diameter of the distribution decreases from $\sim 30 \mathrm{~nm}$ at $11: 00$ to about 16-17 $\mathrm{nm}$ between 11:00-14:00 $\mathrm{h}$. This decrease in mode diameter along with an increase in overall particle numbers, indicates the possibility of new particle formation in the absence of significant changes in traffic during this period. Further, this increase in midday PNC concentration is not observed in December, and the peak declines steadily through the fall. Similar observations in that area have been made previously by Fine et al. (2004b). The inset in Fig. 4b corroborates this argument by showing an increase in particle concentrations in the $25-100 \mathrm{~nm}$ range in the evenings, similar to UPL, which is attributed to the arrival of aged aerosol from the LAB. An increase in mode diameter, along with particle numbers, occurs consistently through the months of September to December for particles $>25 \mathrm{~nm}$ in late afternoon. For 


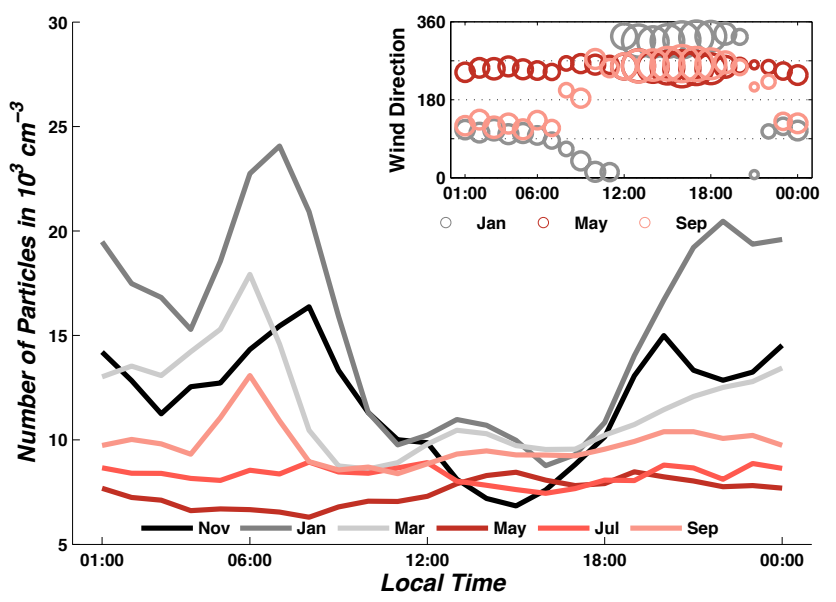

Fig. 4a. Hourly average particle number concentration at AGO for hours of the day in local time. The relative standard error for the hourly averages reported above was less than $3 \%$. The inset is a plot of vector averaged wind direction (WD) with the bubble area weighed to wind speed plotted for hours of the day in local time.

reasons similar to UPL, the effect of local emissions is more pronounced in winter mornings at AGO, as evident in the morning peaks in sub $25 \mathrm{~nm}$ concentrations and the effect of dilution as the day progresses can be seen in the inset in Fig. 3c.

The diurnal pattern in particle concentrations across these sites, (i.e., USC, AGO and UPL) is dominated by a bi-modal distribution, except for summers at USC. The overall particle concentrations decrease due to dispersion as the air parcels move inland (eastwards). The increase in nighttime concentrations (at hours when there are limited fresh emissions) at AGO (easternmost receptor) are lower than at UPL (northern receptor). PNCs at the RUB and VBR sites, which are further inland than UPL, are also lower than at UPL, but higher than at AGO, which is further east of these sites. A similar pattern is observed in the morning peaks corresponding to commute hours, because the traffic volume decreases as one moves farther inland from Downtown Los Angeles.

\subsection{Spatial distribution of particle number concentrations}

Figure 5a and $\mathrm{b}$ compare PNC at all sites for two months (during the warmer and cooler periods of the year) to contrast spatial variation in the concentrations across the basin. A representative month from each season was chosen and data have been plotted as the diurnal averages over the span of the month.

Figure 5a shows a winter month data across sites. The allhour average December 2008 temperatures across the inland sites ranged from 10.7 to $12.7^{\circ} \mathrm{C}$ while the relative humidity ranged from 59 to $67 \%$. The wind data in Table 2 shows the predominant wind direction based on hourly vector av-

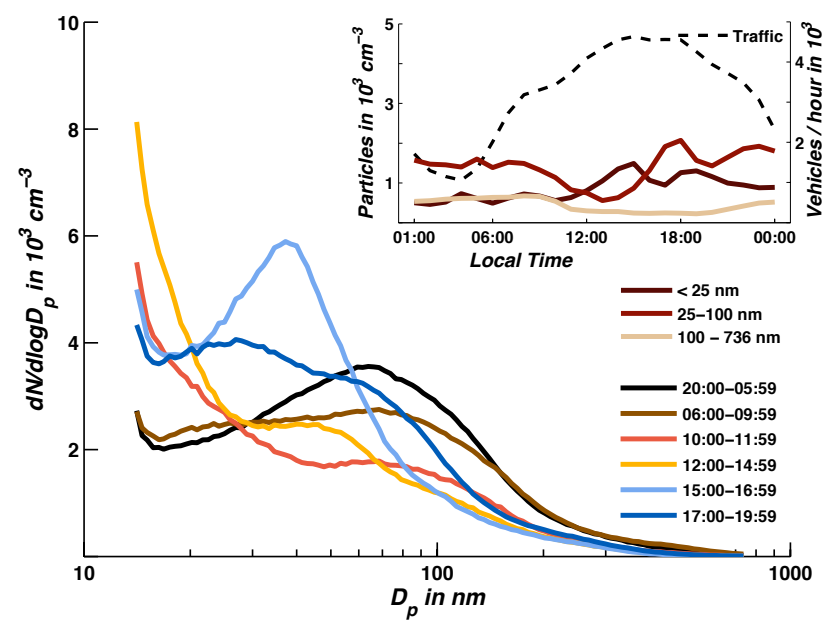

Fig. 4b. Average SizeDistribution of Particles during six time periods (local time) of the day at AGO during September 2009.

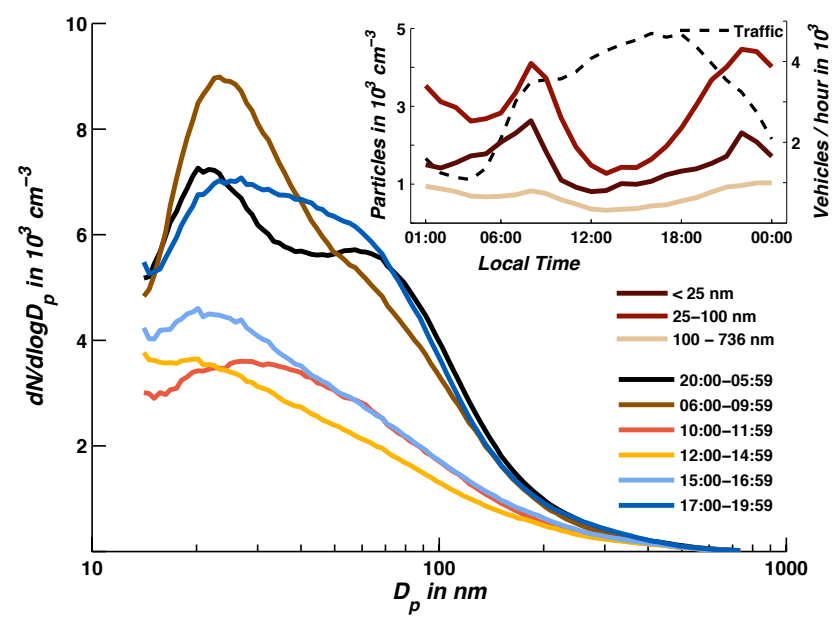

Fig. 4c. Average Size Distribution of Particles during six time periods (local time) of the day at AGO during December 2009.

erages for different sites. At all inland sites, the morning peak concentrations during winter seem to be comparable to those of the nighttime peak (a mix of local evening commute emissions and the arrival of advected PM from urban Los Angeles) that persist for a far longer period than the morning peak does. This is an important observation since it suggests that, in the receptor areas of the LAB, PM transported from central and west Los Angeles can contribute to higher and more sustained concentration levels even during the hours when local sources contribute minimally. These results are also consistent with the findings of Zhu et al. (2006) and $\mathrm{Hu}$ et al. (2009) both conducted in the LAB. The highest of morning concentrations were observed at USC and RUB, the two sites closest to freeways. VBR, which is close to RUB, but farther away from any freeways, had lower concentrations during the morning commute. However, VBR and RUB show excellent agreement in PNC during nighttime, when a 


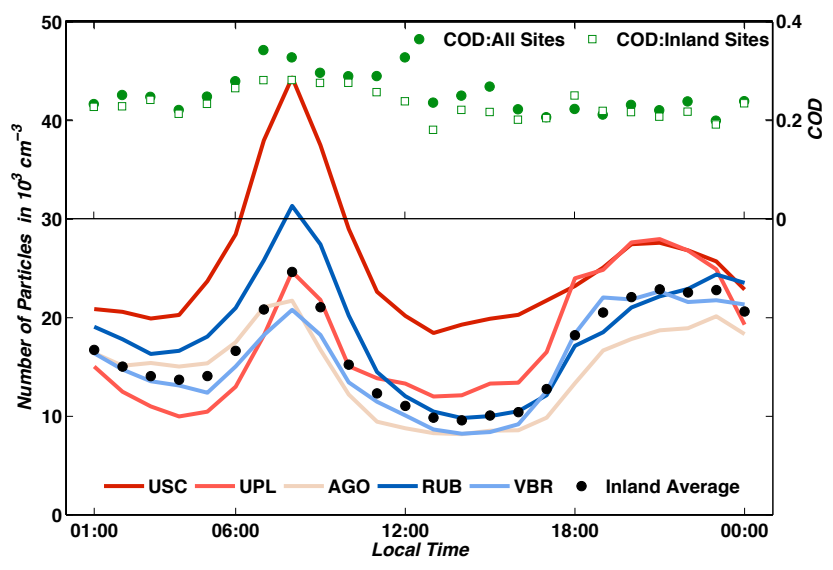

Fig. 5a. PNC and Coefficients of Divergence across sites for December 2008 .

stable stratification predominates the area. UPL (which is closer to USC) and AGO (which is farther east) show higher and lower night time concentrations, respectively, compared to RUB and VBR. The degree of variability based on PNC was examined using the Coefficient of Divergence, and the median value of COD is plotted for all site pairs. The highest CODs, or the maximum spatial variability, are observed during the hours of morning commute. The overall COD range was $0.17-0.28$, indicating that PNC are only moderately heterogeneous.

Figure 5b shows the hourly averages at all sites during August 2009. USC not only has the highest PNC, but also a very sharp midday peak (related to photochemical particle formation), which is comparable to morning traffic-related peak, as discussed earlier. Nighttime PNC become comparable to those at inland sites. The increased PNC pattern during morning commute is observed across all sites even though the numeric values of PNC differ significantly. The morning commute peaks however are not as pronounced as those in winter (December, Fig. 5a) as the primary emissions are quickly dispersed in summer and the higher ambient temperatures may be shifting the partitioning of semivolatile organics emitted by primary sources to the gas phase (Miracolo et al., 2010). Particle number concentrations at all sites were generally lower in summer than in spring or winter. Post midday, there is a steady rise in PNC concentrations in all receptor sites, which is due to the combined effects of photochemical activity along with the contribution of advected PM from western Los Angeles. The overall similarity in PNC data in all sites during overnight hours illustrates a well-dispersed regional-scale aerosol during summer nights. The lowest CODs were observed during summer, with the range for August being 0.13-0.23. These data corroborate the effect of dispersion and advection on regional scales as homogenizing factors leading to low variability at the intercommunity level.

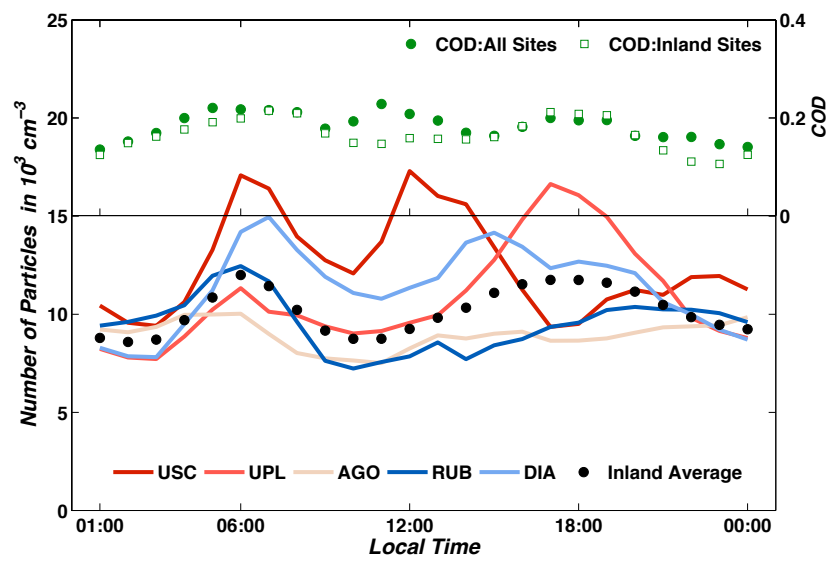

Fig. 5b. PNC and Coefficients of Divergence across sites for August 2009.

The hourly concentrations observed during this campaign varied across seasons, though the diurnal variations were more consistent. The maximum diurnal change in PNCs across seasons was observed at USC, along with the highest average concentrations. This was expected, as USC is located in the immediate vicinity of a freeway (about $120 \mathrm{~m}$ downwind) and in the source region of the LAB. The higher concentrations observed in the fall/winter months were consistent with the work of Singh et al. (2006). In comparison to our earlier study (Moore et al., 2009), which reported concentrations comparable to USC at several sites in the Wilmington and West Long Beach area of Los Angeles, the receptor sites had lower concentrations due to lower impact of heavy traffic emissions in the immediate vicinity. During site selection, preference was given to sites not in the immediate vicinity of a source, to differentiate between local and regional contributions to the measured PNC in these sites. Figure 6 compares the concentrations observed during this study with earlier observations made by Singh et al. (2006), who reported PNC data 6-7 years earlier, using identical instrumentation at similar sites. The sites AGO and UPL are referred to as Riverside and Upland by Singh et al. (2006). The Mira Loma site is about $8 \mathrm{~km}$ west of RUB. In general, the observed concentrations in the present study are somewhat lower, which could be interpreted (with some caution) as an encouraging outcome of the implementation of effective emission control technologies and the replacement of older heavy and light duty vehicles by newer vehicles in the LAB. The seasonal patterns identified in this study are consistent with the earlier observations by Singh et al. (2006).

Figure $7 \mathrm{a}$ and $\mathrm{b}$ compare the CODs across summer and winter periods. Summer seems to be the season with lowest spatial variability; in fact, for the majority of the day, COD values were mostly below 0.2 , indicating remarkable spatial homogeneity for a metropolitan area of this size and complexity in PM sources. The values are generally 


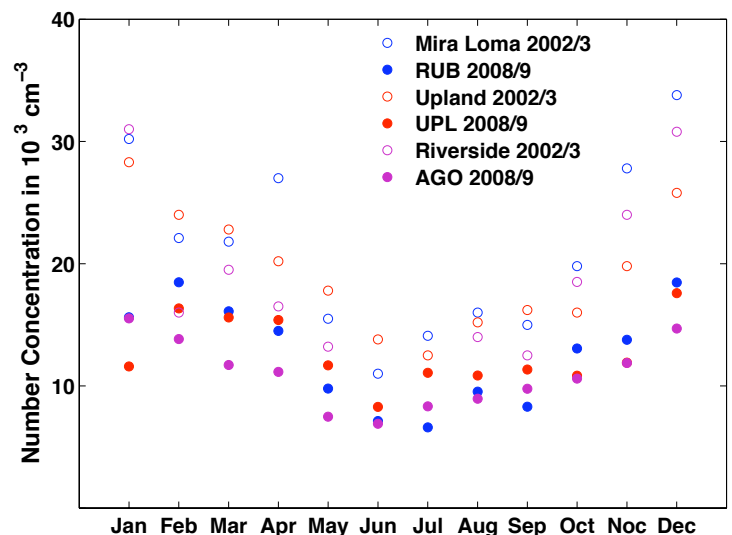

Fig. 6. Comparison of PNC at select sites measured during 2008/09 with Singh et al. (2006) measured during 2002/03.

higher in winter, but still below 0.3 , indicating only moderate heterogeneity. The deviation in CODs for all site pairs was highest for the hours in which primary local sources are predominant, implying that one or more sites with a heavy local influence (which in most cases would be traffic) is increasing the COD. This was further ascertained by inspecting individual site pair values. During both summer and winter, homogeneity is observed in late night and early morning concentrations, indicating the presence of a regional aerosol. In comparison to our previous study (Moore et al., 2009; Krudysz et al., 2009) that reports median COD values of about $0.3-0.5$ in source regions of the LAB (the range between first and third quartiles was on the order of 0.2 units), the values reported in this study are lower. This implies that in LAB, the inter-community variability in PNC is lower than the intra-community variability of areas like the LA harbor, impacted by a multitude of traffic, ship and industrial emissions at a much shorter spatial scale. The relative homogeneity at the inter-community level among receptor sites in LAB can be attributed to the effect of regional transport and meteorology that appear to override the contributions of local primary emissions. The effects of local traffic sources were also observed at the sites in this study, but were restricted to morning and (only during winter) evening commute hours.

The spatial complexity of the PNC was further resolved with the size distribution data. Synergistic effects of multiple factors can lead to similar particle number concentrations at two sites; however, the size distribution profiles may be distinctly different at the two locations due to particle source composition. Wongphatarakul et al. (1998) showed that only moderately heterogeneous COD values can be observed for chemical composition of particles even when the sources are different. Since particle size distribution is as important for exposure classification, the spatial variability was assessed for different PM sizes. Overall CODs varied from 0.400.67 , and exhibited a roughly inverse relationship with particle size. This can in part be accounted for by the difference

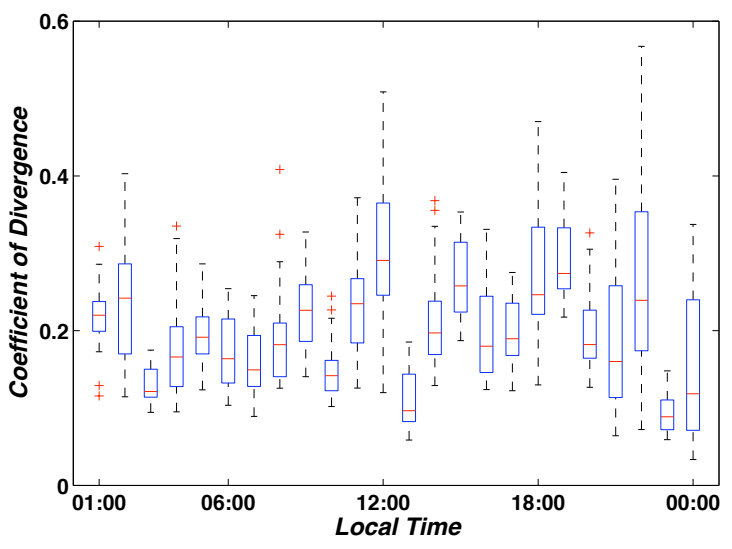

Fig. 7a. Coefficients of divergence during the summer months of May-August, 2009. The red line in the middle is the median and the box bounds the 25th and 75th percentiles of the data. Whiskers indicate the range of data and outliers are identified with red + sign

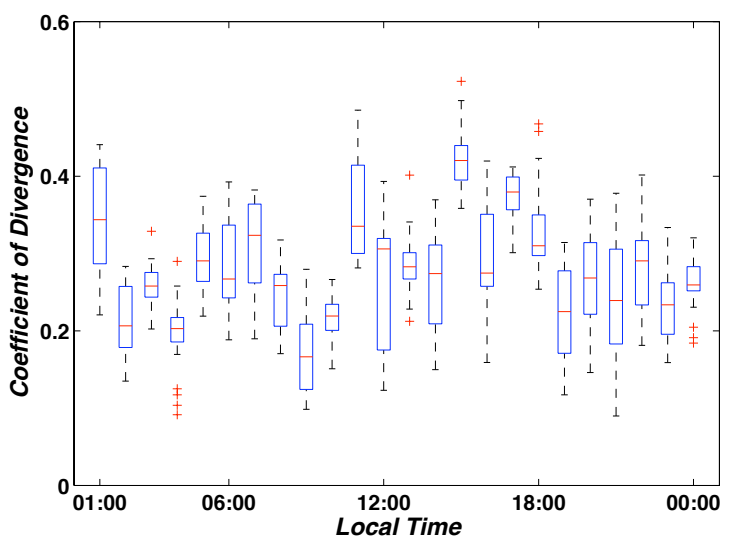

Fig. 7b. Coefficients of divergence during the winter months of December 2008-February 2009. The red line in the middle is the median and the box bounds the 25 th and 75 th percentiles of the data. Whiskers indicate the range of data and outliers are identified with red + sign .

in sources and their magnitude between USC and the inland sites as well as the PM size range, which would affect. This observation is further supported by the lower COD values between the inland sites of AGO-UPL 0.35 (range 0.34-0.36) compared to 0.55 (range 0.53-0.57) for USC-AGO (source and inland site). Even though the degree of spatial heterogeneity is moderate for particles in bigger size ranges, this is the size range with minimal divergence in COD values observed for different site pairs. The data in Fig. 7 reinforce the observation that sites appear to be more homogeneous when the local sources (which contribute to the smaller size spectrum of the particle size distribution more than the bigger size) are not dominant. Similar observations were made by Turner et al. (2002) and Costabile et al. (2009). 


\section{Conclusions}

Moderate inter-community variability in total particle number concentrations was observed across the sites of the eastern Los Angeles Basin. The extreme Coefficient of Divergence (COD) values were often driven by a specific site pair, (site pair varied by hour and season), but the range of upper and lower quartile of COD vales was mostly within 0.1 units, implying that Particle Number Concentration (PNC) in these sites were homogeneous-to-moderately heterogeneous. Although, there were differences in the spatial variability through different seasons, the temporal patterns were consistent, and exhibited least variability in hours when local sources were not dominant. Comparable PNC can be observed in sites separated by several tens of kilometers overnight during stable stratification conditions. The variability in size distributions (reflection of the source composition) was higher than that of total particle number concentrations. Overall the spatial variability in PNC was lower than the values reported by Moore et al. (2009) for intracommunity variability in urban "source" areas of the LAB. The spatial variability based on particle size distributions support the notion of relative homogeneity in receptor areas in LAB, where concentrations are dominated by aged aerosols, advected eastwards from the source regions of urban Los Angeles, since the lowest variability was observed for particles in the size range of $40-100 \mathrm{~nm}$, associated with long-range transport, compared to sub- $30 \mathrm{~nm}$ particles associated with fresh emissions or new particle formation events. The largest differences in PNC were observed between receptor sites and the source site at USC, while PNC were relatively homogeneous among the receptor sites. Further, the data suggest that meteorological conditions can contribute to spatial homogeneity, when phenomena that are regional in nature (i.e., summertime photochemical processes, long range transport, and higher degree of mixing) are active.

Even though our results suggest that PNC are moderately heterogeneous in the polluted receptor areas of the LAB, concerns related to population exposure assessment based on monitoring from a central station are still valid, especially in relation to urban areas impacted by a multitude of local and highly variable sources. Moreover, despite the moderate heterogeneity in total PNC at the inter-community level of receptor sites in $\mathrm{LAB}$, particle size distributions may be significantly variable, resulting in differences in the overall inhaled dose of PM mass. Efforts should be made to characterize the seasonal nature of the variability in both size distributions and number concentrations, because meteorological factors can influence both even when PM sources are similar.
Acknowledgements. We would like to acknowledge Ali Attar, Shruthi Balasubramanian, Niloofar Hajibeiklou and Tina Darjazanie for their assistance in the field and data work. This study was funded by Air Resources Board contract \#05-317. We acknowledge the help of the South Coast Air Quality Management District (P. Fine, R. Bermudez, K. Brown) and UC Riverside (R. Atkinson).

Edited by: W. Birmili

\section{References}

Biswas, S., Ntziachristos, L., Moore, K. F., and Sioutas, C.: Particle volatility in the vicinity of a freeway with heavy-duty diesel traffic, Atmos. Environ., 41, 3479-3493, 2007.

Blumenthal, D. L., White, W. H., and Smith, T. B.: Anatomy of a Los Angeles smog episode: pollutant transport in the daytime sea breeze regime, Atmos. Environ., 12, 893-907, 1978.

Costabile, F., Birmili, W., Klose, S., Tuch, T., Wehner, B., Wiedensohler, A., Franck, U., König, K., and Sonntag, A.: Spatiotemporal variability and principal components of the particle number size distribution in an urban atmosphere, Atmos. Chem. Phys., 9, 3163-3195, doi:10.5194/acp-9-3163-2009, 2009.

Cyrys, J., Pitz, M., Heinrich, J., Wichmann, H., and Peters, A.: Spatial and temporal variation of particle number concentration in Augsburg, Germany, Sci. Total Environ., 401, 168-175, 2008.

Delfino, R. J., Sioutas, C., and Malik, S.: Potential role of ultrafine particles in associations between airborne particle mass and cardiovascular health, Environ. Health Persp., 113, 934-946, 2005.

Delfino, R. J., Staimer, N., Tjoa, T., Gillen, D. L., Polidori, A., Arhami, M., Kleinman, M. T., Vaziri, N. D., Longhurst, J., and Sioutas, C.: Air pollution exposures and circulating biomarkers of effect in a susceptible population: clues to potential causal component mixtures and mechanisms, Environ. Health Persp., 117, 1232-1238, 2009.

Donaldson, K. and MacNee, W.: The Mechanism of Lung Injury Caused by $\mathrm{PM}_{10}$, in: Issues in Environmental Science and Technology, The Royal Society of Chemistry, London, 21-32, 1998.

Englert, N.: Fine particles and human health - a review of epidemiological studies, Toxicol. Lett., 149, 235-242, 2004.

Fine, P. M., Chakrabarti, B., Krudysz, M., Schauer, J., and Sioutas, C.: Diurnal Variations of Individual Organic Compound Constituents of Ultrafine and Accumulation Mode Particulate Matter in the Los Angeles Basin, Environ. Sci. Technol., 38, 1296-1304, 2004a.

Fine, P. M., Shen, S., and Sioutas, C.: Inferring the Sources of Fine and Ultrafine Particulate Matter at Downwind Receptor Sites in the Los Angeles Basin Using Multiple Continuous Measurements, Aerosol Sci. Tech., 38, 182-195, 2004b.

Gong, K. W., Zhao, W., Li, N., Barajas, B., Kleinman, M. T., Sioutas, C., Horvath, S., Lusis, A. J., Nel, A. E., and Araujo, J. A.: Air-pollutant chemicals and oxidized lipids exhibit genomewide synergistic effects on endothelial cells, Genome Biol., 8, R149, doi:10.1186/gb-2007-8-7-4149, 2007.

Harrison, R. M. and Jones, A. M.: Multisite study of particle number concentrations in urban air, Environ. Sci. Technol., 39, 6063$6070,2005$.

Hinds, W. C. (Ed.): Aerosol Technology, 2, John Wiley and Sons, New York, NY, 1999. 
Hricko, A.: Global trade comes home - community impacts on goods movement, Environ. Health Persp., 116, A78-A81, 2008.

Hu, S., Fruin, S., Kozawa, K., Mara, S., Paulson, S. E., and Winer, A. M.: A wide area of air pollutant impact downwind of a freeway during pre-sunrise hours, Atmos. Environ., 43, 2541-2549, 2009.

Jerrett, M., Burnett, R. T., Ma, R., Pope, C. A., Krewski, D., Newbold, K. B., Thurston, G., Shi, Y., Finkelstein, N., Calle, E. E., and Thun, M. J.: Spatial Analysis of Air Pollution and Mortality in Los Angeles, Epidemiology, 16, 727-736, 2005.

Kim, S., Shen, S., and Sioutas, C.: Size distribution and diurnal and seasonal trends of ultrafine particles in source and receptor sites of the Los Angeles basin, J. Air Waste Manage., 52, 297-307, 2002.

Kleeman, M. J., Hughes, L. S., Allen, J. O., and Cass, G. R.: Source contributions to the size and composition distribution of atmospheric particles: Southern California in September 1996, Environ. Sci. Technol., 33, 4331-4341, 1999.

Krudysz, M., Moore, K., Geller, M., Sioutas, C., and Froines, J.: Intra-community spatial variability of particulate matter size distributions in Southern California/Los Angeles, Atmos. Chem. Phys., 9, 1061-1075, doi:10.5194/acp-9-1061-2009, 2009.

Kulmala, M., Vehkamaki, H., Petaja, T., Dal Maso, M., Lauri, A., Kerminen, V. M., Birmili, W., and McMurry, P. H.: Formation and growth rates of ultrafine atmospheric particles: a review of observations, J. Air Waste Manage., 35, 143-176, 2004.

Li, N., Sioutas, C., Froines, J. R., Cho, A., Misra, C., and Nel, A.: Ultrafine particulate pollutants induce oxidative stress and mitochondrial damage, Environ. Health Persp., 111, 455-460, 2003.

Lianou, M., Chalbot, M. C., Kotronarou, A., Kavouras, I. G., Karakatsani, A., Katsouyanni, K., Puustinnen, A., Hameri, K., Vallius, M., Pekkanen, J., Medings, C., Harrison, R. M., Thomas, S., Ayres, J. G., ten Brink, H., Kos, G., Meliefste, K., de Hartog, J. J., and Hoek, G.: Dependence of home outdoor particulate mass and number concentrations on residential and traffic features in urban areas, J. Air Waste Manage., 57, 1507-1517, 2007.

Lu, R. and Turco, R. P.: Air pollutant transport in a coastal environment. Part I: Two-Dimensional Simulations of Sea-Breeze and Mountain Effects, J. Atmos. Sci., 51, 2285-2308, 1994.

Lu, R. and Turco, R. P.: Air pollutant transport in a coastal environment - II. Three-dimensional simulations over Los Angeles basin, Atmos. Environ., 29, 1499-1518, 1995.

McElroy J. L. and Smith T. B.: Creation and fate of ozone layers aloft in Southern California, Atmos. Environ., 27A, 1917-1929, 1993.

McElroy J. B. and Smith T. B.: Vertical pollutant distributions and boundary layer structure observed by airborne lidar near the complex Southern California coastline, Atmos. Environ., 20, 15551566, 1986.

Miracolo, M. A., Presto, A. A., Lambe, A. T., Hennigan, C. J., Donahue, N. M., Kroll, J. H., Worsnop, D. R., and Robinson, A. L.: Photo-Oxidation of Low-Volatility Organics Found in Motor Vehicle Emissions: Production and Chemical Evolution of Organic Aerosol Mass, Environ. Sci. Technol., 44, 1638-1643, 2010.

Monn, C.: Exposure assessment of air pollutants: A review on spatial heterogeneity and indoor/outdoor/personal exposure to suspended matter, nitrogen dioxide and ozone, Atmos. Environ., 35,
$1-32,2001$.

Moore, K. F., Ning, Z., Ntziachristos, L., and Sioutas, C.: Daily variation in summer urban ultrafine particle properties - physical characterization and volatility, Atmos. Environ., 41, 8633-8646, 2007.

Moore, K. F., Krudysz, M., Pakbin, P., Hudda, N., and Sioutas, C.: Intra-Community Variability in Total Particle Number Concentrations in the San Pedro Harbor Area (Los Angeles, California), Aerosol Sci. Tech., 43, 587-603, 2009.

Motallebi, N., Tran, H., Croes, B. E., and Larsen, L. C.: Day-ofweek patterns of particulate matter and its chemical components at select sites in California, J. Air Waste Manage., 53, 876-888, 2003.

Morawska, L., Thomas, S., Bofinger, N., Wainwright, D., and Neale, D.: Comprehensive Characterization of Aerosols in a Subtropical Urban Atmosphere: Particle Size Distribution and Correlation with Gaseous Pollutants, Atmos. Environ., 32, $2467-$ 2478, 1998.

Nel, A.: Air pollution-related illness: effects of particles, Science, 308, 804-806, 2005.

Ning, Z., Geller, M., Moore, K. F., Sheesley, R., Schauer, J. J., and Sioutas, C.: Daily variation in summer urban ultrafine aerosols and inference of their sources, Environ. Sci. Technol., 41, 60006006, 2007.

Oberdörster, G., Gelein, R. M., Ferin, J., and Weiss, B.: Association of Particulate Air Pollution and Acute Mortality: Involvement of Ultrafine Particles, Inhal. Toxicol., 7, 111-124, 1995.

Pandis, S. N., Harley, R. A., Cass, G. R., and Seinfeld, J. H.: Secondary Organic Aerosol Formation and Transport, Atmos. Environ. A-Gen., 26, 2269-2282, 1992.

Penttinen, P., Timonen, K. L., Tiittanen, P., Mirme, A., Ruuskanen, J., and Pekkanen, J.: Ultrafine particles in urban air and respiratory health among adult asthmatics, Eur. Respir. J., 17, 428-435, 2001.

Pekkanen, J., Timonen, K. L., Ruuskanen, J., Reponen, A., and Mirme, A.: Effects of ultrafine and fine particles in urban air on peak expiratory flow among children with asthmatic symptoms, Environ. Res., 74, 24-33, 1997.

Peters, A., Wichmann, H. E., Tuch, T., Heinrich, J., and Heyder, J.: Respiratory Effects are Associated with the Number of Ultrafine Particles, Am. J. Respir. Crit. Care Med., 155, 1376-1383, 1997.

Pope, C. A. and Dockery, D. W.: Health effects of fine particulate air pollution: lines that connect, J. Air Waste Manage., 56, 709742, 2006

Phuleria, H. C., Geller, M. D., Fine, P. M., and Sioutas, C.: Sizeresolved emissions of organic tracers from light and heavy-duty vehicles measured in a California roadway tunnel, Environ. Sci. Technol., 40, 4109-4118, 2006.

Puustinen, A., Hameri, K., Pekkanen, J., Kulmala, M., de Hartog, .J, Meliefste, K., ten Brink, H., Kos, G., Katsouyanni, K., Karakatsani, A., Kotronarou, A., Kavouras, I., Meddings, C., Thomas, S., Harrison, R. M., Ayres, J. G., van der Zee, S., and Hoek, G.: Spatial variation of particle number and mass over four European cities, Atmos. Environ., 41, 6622-6636, 2007.

Ronkko, T., Virtanen, A., Vaaraslahti, K., Keskinen, J., Pirjola, L., and Lappi, M.: Effect of dilution conditions and driving parameters on nucleation mode particles in diesel exhaust: Laboratory and on-road study, Atmos. Environ., 40, 2893-2901, 2006.

Ronkko, T., Virtanen, A., Kannosto, J., Keskinen, J., Lappi, M., and 
Pirjola, L.: Nucleation mode particles with a nonvolatile core in the exhaust of a heavy duty diesel vehicle, Environ. Sci. Technol., 41, 6384-6389, 2007.

Rodríguez, S., Van Dingenen, R., Putaud, J.-P., Dell'Acqua, A., Pey, J., Querol, X., Alastuey, A., Chenery, S., Ho, K.-F., Harrison, R., Tardivo, R., Scarnato, B., and Gemelli, V.: A study on the relationship between mass concentrations, chemistry and number size distribution of urban fine aerosols in Milan, Barcelona and London, Atmos. Chem. Phys., 7, 2217-2232, doi:10.5194/acp-7-2217-2007, 2007.

Sardar, S. B., Fine, P. M., Yoon, H., and Sioutas, C.: Associations between particle number and gaseous co-pollutant concentrations in the Los Angeles basin, J. Air Waste Manage., 54, 9921005, 2004.

Schauer, J. J., Kleeman M. J., Cass, G. R., and Simoneit, B. R. T.: Measurements of emissions from air pollution sources. 3. C1-c29 organic compounds from fireplace combustion of wood, Environ. Sci. Technol., 35, 1716-1728, 2001.

Shi, J. P., Evans, D. E., Khan, A. A., and Harrison, R. M.: Sources and Concentrations of Nanoparticles ( $<10-\mathrm{nm}$ Diameter) in the Urban Atmosphere, Atmos. Environ., 35, 1193-1202, 2001.

Singh, M., Phuleria, H. C., Bowers, K., and Sioutas, C.: Seasonal and spatial trends in particle number concentrations and size distributions at the Children's Health Study Sites in Southern California, J. Expo. Env. Epid., 16, 3-18, 2006.

Sioutas, C., Delfino, R. J., and Singh, M.: Exposure assessment for atmospheric ultrafine particles (UFPs) and implications in epidemiological research, Environ. Health Persp., 113, 947-955, 2005.

Tuch, T. M., Herbarth, O., Franck, U., Peters, A., Wehner, B., Wiedensohler, A., and Heintzenberg, J.: Weak correlation of ultrafine aerosol particle concentrations $<800 \mathrm{~nm}$ between two sites in one city, J. Expo. Env. Epid., 16, 486-490, 2006.

Turner, J. R. and Allen, D. T.: Transport of atmospheric fine particulate matter: part 2 - findings from recent field programs on the intraurban variability in fine particulate matter, J. Air Waste Manage., 58, 196-215, 2008.

Ulrickson B. L. and Mass C. F.: Numerical investigation of mesoscale circulations over the Los Angeles Basin. Part II: synoptic influences and pollutant transport, Mon. Weather Rev., 118, 2162-2184, 1990.

Verma, V., Ning, Z., Cho, A. K., Schauer, J. J., Shafer, M. M., and Sioutas, C.: Redox activity of urban quasi-ultrafine particles from primary and secondary sources, Atmos. Environ., 43, 6360-6368, 2009.

Wakimoto R. M. and McElroy J. L.: Lidar observations of elevated pollution layers over Los Angeles, J. Clim. Appl. Met., 25, 1583 1598, 1986.
Wehner, B., Siebert, H., Stratmann, F., Tuch, T., Wiedensohler, A., Petaja, T., Dal Maso, M., and Kulmala, M.: Horizontal homogeinity and vertical extent of new particle formation events, Tellus, 59B, 362-371, 2007.

Westerdahl, D., Fruin, S., Sax, T., Fine, P. M., and Sioutas, C.: Mobile platform measurements of ultrafine particles and associated pollutant concentrations on freeways and residential streets in Los Angeles, Atmos. Environ., 39, 3597-3610, 2005.

Wilson, J. G., Kingham, S., Pearce, J., and Sturman, A.: A review of intraurban variations in particulate air pollution: implications for epidemiological research, Atmos. Environ., 39, 6444-6462, 2005.

Wongphatarakul, V., Friedlander, S. K., and Pinto, J. P.: A comparative study of $\mathrm{PM}_{2.5}$ ambient aerosol chemical databases, Environ. Sci. Technol., 32, 3926-3934, 1998.

Xia, T., Korge, P., Weiss, J. N., Li, N., Venkatesen, M. I., and Sioutas, C.: Quinones and aromatic chemical compounds in particulate matter induce mitochondrial dysfunction: implications for ultrafine particle toxicity, Environ. Health Persp., 112, 13471358, 2004.

Xia, T., Kovochich, M. J., Brant, J., Hotze, M., Sempf, J., Oberley, T., Yeh, J., Sioutas, C., Wiesner, M. R., and Nel, A. E.: Comparisons of the abilities of ambient and commercial nanoparticles to induce cellular toxicity according to an oxidative stress paradigm, Nano Lett., 6, 1794-1807, 2006.

Zhang, K. M. and Wexler, A. S.: Modeling the Number Distributions of Urban and Regional Aerosols: Theoretical Foundations, Atmos. Environ., 36, 1863-1874, 2002.

Zhu, Y., Hinds, W. C., Kim, S., Shen, S., and Sioutas, C.: Study on ultrafine particle and other vehicular pollutants near a major highway with heavy duty diesel traffic, Atmos. Environ., 36, 4323-4335, 2002a.

Zhu, Y., Hinds, W. C., Kim, S., and Sioutas, C.: Concentrations and size distribution of ultrafine particles near a major highway, J. Air Waste Manage., 52, 1032-1042, 2002b.

Zhu, Y., Hinds, W. C., Shen, S., and Sioutas, C.: Seasonal trends of concentration and size distributions of ultrafine particles near major highways in Los Angeles, Aerosol Sci. Technol., 38, 5-13, 2005.

Zhu, Y., Kuhn, T., Mayo, P., and Hinds, W. C.: Comparison of daytime and nighttime concentration profiles and size distributions of ultrafine particles near a major highway, Environ. Sci. Technol., 40, 2531-2536, 2006. 